\title{
Application of Order as Character Education in Santriwati Islamic Boarding School Jagad Alimussiry
}

\author{
E Zubaidah \\ Islamic Building School of Jagad Alimussirry Surabaya, Indonesia \\ Email: enyzubaidah19@gmail.com
}

\begin{abstract}
Every institution has its own way or method of applying character education where the lessons of values, ethics, morals and religious teachings are the main focus. The boarding school has a different educational pattern than the one in general. At the Islamic Boarding School Jagad 'Alimussirry, students have a set of rules that are used in practice in the daily schedule of students. The daily schedule of activities was a means of implementing the practice for the students under the supervision of the lodge managers. All activities have different areas of management to assist and supervise students character education is not just about the young budding education process that is tapping into the formation of the school, it is also about the individual within the educational institution. Basically, in order to be a responsible individual in society, each individual must develop a wide range of potentials within himself, especially promoting morals that will serve as a guide for their role models within the institution.
\end{abstract}

Keywords: Implementation of order; character education

\section{INTRODUCTION}

Education is a matter that has a role important in the life of man, things that indicate that every human being or individual has the right to get and to always evolve in terms of education. Education in general has meaning a process in life that is aimed at developing self of each individual to be able to live and perpetuate of life, so to be one that is educated it became important. But education in schools is only a transfer value where the teacher gives the material or teaching material and students only receive and be tested in examinations at the end of each semester.

Education characters themselves according to the dictionary great language Indonesia, educational character of a nature psychological, behavior or mind and character that became typical of someone. So that the characters a person can be a differentiator with other people (www.informasi-pendidikan.com/ accessed on the date of 24 March 2018) Education characters in it are the planting of three terms of principle namely

1. Akhlaq

2. Moral Ethics

3. Score.

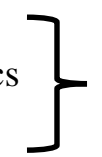

To form

The point here is education of character is a system that is used to instill the value of religion, ethis and values are positive to the child so that the forming moral self- child. Morals that have mentioned above are habits, customs and traditions, and behaviors that had become a habit, or can be said that the moral is polite manners. Often people who apply different or contrary to the custom in the environment certain to be in say not immoral. 


\section{A. Character Education in Islamic Boarding Schools}

Islamic Boarding School as one of the subsystem of National Education that indigenous Indonesia, has advantages and characteristics particular to apply the education of character for children of their students (students). That's because: There is a Soul and Philosophy. Islamic Boarding School has a soul and philosophy are implanted to the children of their students. Soul and philosophy is this that will ensure the survival of an institution of education even become the motor driving force towards progress in the future.

The transformation of the values of Islamic Boarding School education that takes place throughout the year, through various means (oral, written acts and reality), has been able to integrate all components of Islamic Boarding School in one line. So that there is no conflict of interests and orientation between one party and another. Everything underlying motion pace with the language of sincerity, simplicity, sincerity, struggle and sacrifice to achieve the pleasure of Allah. All have the understanding and calling for responsibility to realize the vision and mission of the Islamic Boarding School education.

This organizational education is also for leadership regeneration through selfgovernment education. Meanwhile, at the cottage level there is an organization of its own , consisting of the chairman of the hut, the security, religious, talent and interest development, treasurer and regent chambers . The entire activity which handled the organization cottage is escorted and guided by the seniors they are composed of the ustadzcleric and student seniors who already believed to help take care of the cottage. In direct every activity hut that will do the students is taken care of by Mr. Leader cottage which as well as caretakers cottage.

\section{B. Application of Order in Islamic Boarding School}

In the cultivation of discipline in the context of character building and moral formation in santri, the emphasis is on a number of santri activities. When negligent in the implementation of activities while in Islamic Boarding School Jagad 'Alimussirry, students can be subject to sanctions in accordance with the provisions of the Standing Orders.

Rules of Conduct Students (TIBSAR) there is a grouping of the articles is important that aimed to discipline students, among others are:

1. Worship Discipline

2. Discipline of politeness

3. Discipline of education and teaching

4. Discipline in organization

5. Discipline to pay sharia

6. Discipline to maintain environmental security and order

7. Discipline to maintain the cleanliness of the cottage

8. Discipline follows every event at the Islamic Boarding School

9. The Discipline of Living in a Cottage

The nine disciplines are summarized in the book layout orderly students are required to be adhered to and always applied by kesantrian through the organization committee cottage. This is an embodiment of the Scaffolding learning model with the habituation method. In the cottage Islamic Boarding School Jagad 'Alimussirry a cottage students finished the activities which do not so burdensome or too full in the morning until night. Only just the more major is in the activity schedule of the Koran that has been applied every day.

\section{Schedule for Non Formal S1 Study}

The life of the students while they were in the cottage was scheduled so that the students only needed to obey the daily schedule in a disciplined manner. Every activity that is scheduled to Santi Islamic Boarding School Jagad 'Alimussirry the intent and purpose for female students who run it, when there is a 
violation or non-compliance of students it will be no form of punishment so that students still adhere to the rules and schedules that are already in the set. Forms of punishment which is in the practices also vary and have levels in accordance with the type of violation or non respect against the rules and schedules are valid , because each activity has a rate of interest that is different between one to the other .

Proses educational character will run through the implementation of governance discipline students where sanctions are given is to educate and provide additional knowledge or knowledge new to the students. Pupils are taught to have a sense of shame to abuse because of the sanctions that are given also is sanctioned socially.

The custom of the discipline since the beginning of the new school year and began to be introduced and applied to the new santri made the students become accustomed to following all the rules in the Islamic Boarding School Jagad 'Alimussirry. One by one form of habituation in introducing such: Still time to follow the Koran , right time each activity both formal and non-formal, discipline maintain the cleanliness of the environment, discipline Return to lodge no more than 10 hours a night, the right time to pay sharia cottage and other so on .

Model refraction which apply in Islamic Boarding School Jagad 'Alimussirry referred to as conditioning, which is an attempt to establish the behavior of certain by way of practicing it repeatedly. According to Gagne model of learning like this is called a Direct method as used in deliberate and aimed to change behavior (Gagne, 1992: 88). The conditioning model belongs to the behaviorism approach. In everyday learning with models such as the above is a form of modified behavior behavior of individuals as a result of the experience that is formed from the exercise continue constantly or habituation. Dwi Cahyani regarding the goals of habituation namely:
"The goal is to familiarize the students apply the discipline, have a behavior that is either so do not hurt yourself alone and others. Tata order to make the students to be able meet the values of religious, values moral, and social. If not there is order orderly so might the life of the cottage will be free and do not exist achievement that can by the students after graduation. "

Life for at Islamic Boarding School Jagad 'Alimussirry has been arranged in such a form and expect students to achieve benefits for life after graduation from the cottage and even better if accompanied by habituation themselves for at Islamic Boarding School Jagad 'Alimussirry that can be consistent is forever without forgotten

\section{CONCLUSION}

Each institution of education has a variety of ways or methods to implement educational character where the lesson that contains values, ethics, morals and teachings of religion is a matter main which became the focus. Islamic Boarding School has a pattern of education that is different from the pattern of education in general. In schools there is supervision that strict regarding governance norms or values, especially about the behavior of worship special and norms mu'amalat particular. Guidance and norms learn so quickly clever and quick completion may be said almost did not exist. So, education in Islamic Boarding School the emphasis is not on cognitive aspects, but rather on the affective and psychomotor aspects.

At Islamic Boarding School Jagad 'Alimussirry own governance orderly students are used as a habituation that is applied in the schedule of the students in the form of a cycle of activities daily. Schedule activities that are repeated every day becomes a means of application of refraction for the students to be supervised by the caretaker cottage. All activities are areas of the board that is different to accompany and supervise the students. 
Learning is kept constantly and repeatedly in Islamic Boarding School Jagad 'Alimussirry which is a form of application of the system in an orderly students as an educational character to facilitate the students to be personally that much better. So that the students can achieve education formal good and can compete with the school public without forgetting the importance of education of religion, ethics, and values well as forming morals for children.

Education characters actually not just dealing with the process of education shoots young who were process period of formation in the school, but also for every individual in the institution of education. For the essentially, to be individuals who are responsible in the society, every individual must develop various kinds of potentials that exist in themselves, especially strengthen the moral will be a guide for practice them in the institution.

The role of institutions of education schools in shaping the character generation successor not be seen next to the eye. Educational boarding schools associated closely with education -based morals that teach participants their students to have a character strong in forming and confirming personal that character.

\section{REFERENCES}

[1] Mastuhu, Dinamika sistem pendidikan pesantren, Jakarta: INIS, 1994.

[2] Khozin, Jejak-jejak Pendidikan Islam di Indonesia Rekonstruksi Sejarah Untuk. Aksi, Malang: UMM Press, 2006.

[3] Gagne, Robert M, Leslie J. Briggs, Walter W. Wager, Principles of Instructional Design, Bellmont-CA: Thompson Learning, 1992.

[4] www.informasi-pendidikan.com/ diakses pada tanggal 24 Maret 2018. 